\title{
Estimating the burden of neural tube defects in low- and middle-income countries
}

\author{
Annie Lo ${ }^{1}$, Dora Polšek ${ }^{2}$, \\ Simrita Sidhu ${ }^{1}$ \\ ${ }^{1}$ The University of Edinburgh Medical School, \\ Edinburgh, Scotland, UK \\ ${ }^{2}$ Histology and Embryology Department, \\ School of Medicine, University of Zagreb, \\ Zagreb, Croatia
}

\begin{abstract}
Background To provide an estimate for the burden of neural tube defects (NTD) in low- and middle-income countries (LMIC) and explore potential public health policies that may be implemented. Although effective interventions are available to prevent NTD, there is still considerable childhood morbidity and mortality present in LMIC.

Methods A search of Medline, EMBASE, Global Health Library and PubMed identified 37 relevant studies that provided estimates of the burden of NTD in LMIC. Information on burden of total NTD and specific NTD types was separated according to the denominator into two groups: (i) estimates based on the number of live births only; and (ii) live births, stillbirths and terminations. The data was then extracted and analysed.
\end{abstract}

Results The search retrieved NTD burden from 18 countries in 6 WHO regions. The overall burden calculated using the median from studies based on livebirths was $1.67 / 1000$ (IQR $=0.98-3.49)$ for total NTD burden, $1.13 / 1000$ (IQR=0.75-1.73) for spina bifida, 0.25/1000 (IQR $=0.08-1.07)$ for anencephaly and $0.15 / 1000(\mathrm{IQR}=0.08-0.23)$ for encephalocele. Corresponding estimates based on all pregnancies resulting in live births, still births and terminations were 2.55/1000 (IQR $=1.56-3.91)$ for total NTD burden, 1.04/1000 (IQR $=0.67-$ 2.48) for spina bifida, $1.03 / 1000$ ( $I Q R=0.67-1.60)$ for anencephaly and $0.21(\mathrm{IQR}=0.16-0.28)$ for encephalocele. This translates into about 190000 neonates who are born each year with NTD in LMIC.

Conclusion Limited available data on NTD in LMIC indicates the need for additional research that would improve the estimated burden of NTD and recommend suitable aid policies through maternal education on folic acid supplementation or food fortification.

\section{Correspondence to:}

Annie Lo

Centre for Population Health Sciences

The University of Edinburgh Medical School

Teviot Place, Edinburgh EH8 9AG

Scotland, UK

a.lo@sms.ed.ac.uk
Every year, more than 300000 children are born with neural tube defects (NTD) [1-6]. NTD are a group of congenital abnormalities that still cause hundreds of thousands of deaths in $0-4$ years age group, while similar number of surviving children remain disabled for life [1-6]. One of the Millennium Development Goals initiated by the United Nations was dedicated to reducing global mortality rates of children in this age group. Since 1990, global child mortality has been declining largely due to the focus on communicable diseases, which included the expansion of immunisation programmes, promotion of breast-feeding and increased provision of mosquito bednets in many countries worldwide [2]. This reduc- 
tion of mortality has led to the neglected causes of child mortality to be exposed, including that of congenital abnormalities [3-6].

NTD are one of the most common presenting birth defects, arising as a result of incomplete closure of the brain or spinal cord in the $3^{\text {rd }}$ and/or $4^{\text {th }}$ week of pregnancy [3]. NTD can be classified as open or closed, depending on whether neural tissues are exposed or covered by skin, respectively. Open NTD are more frequent and include spina bifida, anencephaly and encephalocele. Closed NTD, such as tethered cord syndrome, are less frequent in comparison [4].

The best known risk factor for foetal NTD is maternal folate deficiency, arising from low levels of vitamin B9 (folic acid) $[7,8]$. Maternal vitamin B12 deficiency has only recently been shown to independently contribute to risk of NTD $[9,10]$. Additional risk factors for NTD development include a positive family history, smoking and indoor air pollution from coal and biomass heating used predominantly in developing countries [11-15]. Moreover, NTD are related to maternal socio-economic status, education, area of residence, and maternal nutrient deficiency or obesity $[16,17]$.

NTD can be identified through simple prenatal testing using ultrasound imaging or maternal serum alpha-fetoprotein (MSAFP) level screening [18]. Abnormal elevation of MSAFP is a relatively specific and sensitive test for detection of NTD [18]. The abnormal presence of acetylcholinesterases (AChE) in amniotic fluid determined through amniocentesis can also be used for screening of NTD. However, a higher-than-normal test result is often not diagnostic and further evaluation should always be undertaken $[19,20]$.

Since the discovery of folic acid as an effective intervention for prevention of neural tube defects [21], many countries have recommended folic acid intake before conception and during pregnancy. However, the dramatic 20\% decrease in NTD birth burden after mandatory folic acid fortification (FAF) of enriched products in the US in 1998 showed that there may be more practical ways to administer this intervention [22]. Since this example, many countries such as Chile, Saudi Arabia and South Africa have implemented similar measures to staple food [23-25]. Despite folic acid being a well-known, cost-effective intervention, many developing countries continue to have either ineffective or no policy to increase maternal uptake of folic acid to prevent NTD.

The aims and objectives of this systematic review were:

1. To provide an estimate of NTD burden in LMIC by systematically reviewing literature available in public domain;

2. To examine and discuss the significance of these findings and consider clinical and cost-effective interventions and health policies with regards to NTD.

\section{METHODS}

A systematic literature review was conducted to search for published literature regarding population-based NTD burden estimates in LMIC, through the use of electronic databases: Medline, Embase, Global Health Library and PubMed. Potential further data were searched for on Google Scholar and by crosschecking reference lists from review articles. The search used Medical Subject Headings (MeSH) and key words for the burden of NTD in LMIC, as outlined by the World Bank. Limits of "human" and "2000_ current" were used to obtain the most up to date NTD burden information. The last searches of the four databases were conducted on 6 February 2013. Search terms for Medline are shown in Table 1 and were modified for other databases as required.

Table 1. Search terms for Medline

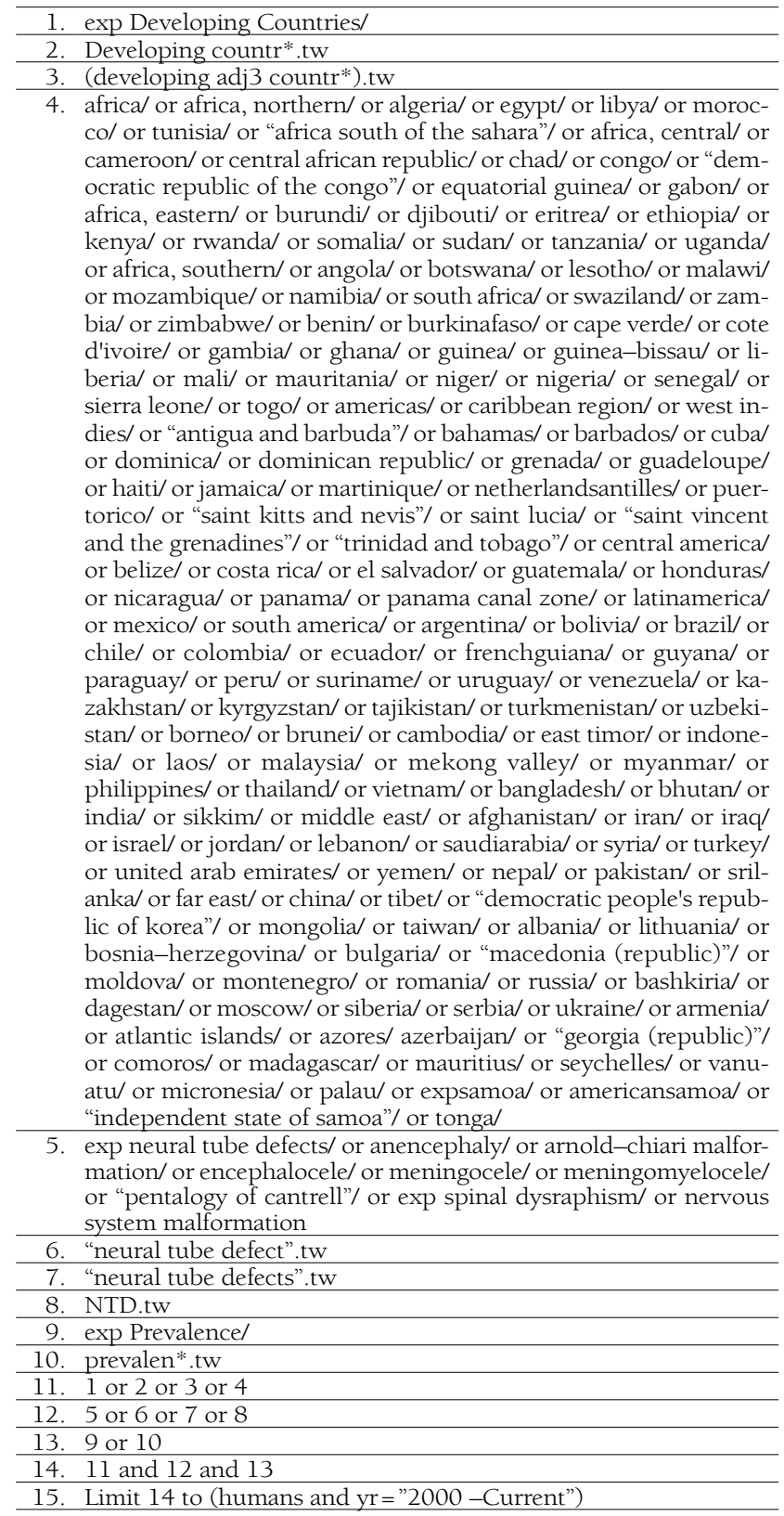




\section{Study selection}

The inclusion criteria for relevant papers included population or hospital based studies conducted in LMIC, which were geographically defined taking into account both the World Health Organization's and the World Bank's classification and treating any discrepancies in an inclusive, rather than exclusive way. The studies needed to have clearly expressed NTD burden showing a denominator, published between 2000 and 2013. The searches were limited to the period after the year 2000 in order to generate an estimate that is reflective of reasonably recent NTD trends. No limit on language and publication type was set. Keeping in mind that many babies with NTD are stillborn or terminated through miscarriages and abortions, we decided to include studies with live births, stillbirths and terminations as a separate body of evidence, in addition to studies that used live births-based denominators to report the burden of NTD.

Studies conducted solely in specialist hospital units were excluded, as they are likely to report a burden enriched for severe cases that would not be representative of the general population. Studies with incomplete data or where NTD burden could not be calculated were also excluded.

\section{Data extraction}

For the 37 retained studies, relevant data were extracted and compiled into Microsoft Excel spreadsheets. Data including authors, country, study size and diagnostic criteria for specific NTD type and total NTD cases were extracted. Types of NTD included spina bifida, myelomeningocele, meningocele, anencephaly, encephalocele and "other NTD types". Burden was expressed using the number of cases observed and a total sample of live births (or, alternatively, a total sample of live births, stillbirths and terminations).

\section{Data analysis}

When the number of affected children was not specifically provided in the study, it was calculated with the sample population using the following equation:

Estimated NTD burden = Number of observed NTD cases/ Sample size (eg, number of live births) $\times 1000$

The estimates of the burden provided in the retained studies were separated into two categories: those in which the denominator was based on the number of live births, and the other group in which live births, stillbirths and terminations were all included. Wherever this information was available for both categories, figures were separately added to the respective groups. The median estimate of the NTD burden and the inter-quartile range (IQR) for all LMIC regions was then determined, based on the retained 37 studies. Eventually, the median was multiplied by the number of livebirths in LMIC in the year 2010, according to UN Population Division's estimates (www.un.org/esa/population/), to determine the absolute number of NTD cases that has been introduced to the LMIC in 2010.

\section{RESULTS}

A review of relevant databases performed independently by two researchers (AL and SS) identified a total of 3339 studies, but only 37 satisfied all criteria for inclusion (as shown in Figure 1). Of the retained studies, 20 reported NTD rates in live births only, 14 reported rates in live births, stillbirths and terminations combined, and 3 studies reported both.

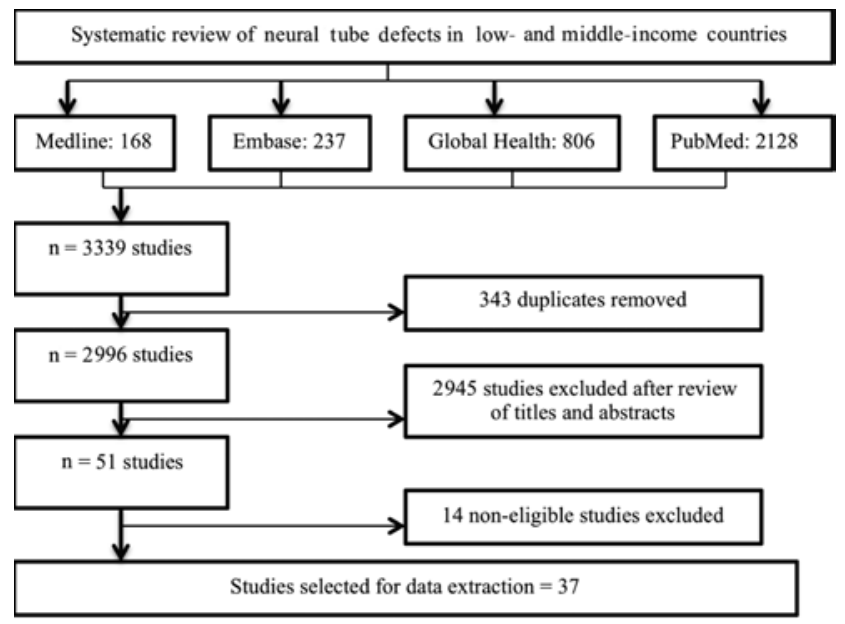

Figure 1. A summary of the process of literature search.

The median sample size from all reviewed papers was 36331, which corresponded well to a typical study size. The median sample population in studies based on live births was 35974, compared to 49534 in studies based on live births, stillbirths and terminations.

The search retrieved NTD burden from 18 countries in 6 WHO regions (Table 2). The overall burden calculated using the median from studies based on live births was 1.67/1000 (IQR $=0.98-3.49$ ) for total NTD burden (Table 3 and 4), 1.13/1000 (IQR=0.75-1.73) for spina bifida (Table 3 and 5), 0.25/1000 (IQR=0.08-1.07) for anencephaly (Table 3 and 6) and 0.15/1000 (IQR=0.08-0.23) for encephalocele (Table 3 and 7).Corresponding estimates based on all pregnancies resulting in live births, still births and terminations were 2.55/1000 (IQR $=1.56-3.91)$ for total NTD burden (Table 3 and 8), 1.04/1000 (IQR $=0.67-2.48$ ) for spina bifida (Table 3 and 9), 1.03/1000 (IQR=0.67-1.60) for anencephaly (Table 3 and 10) and 0.21 (IQR=0.160.28 ) for encephalocele (Table 3 and 11). This translates into about 190000 neonates who are born each year with NTD in LMICs. 
Table 2. Distribution of retained studies by WHO regions

\begin{tabular}{|c|c|c|c|c|}
\hline \multirow[b]{2}{*}{ WHO REGION } & \multirow[b]{2}{*}{ Countay } & \multicolumn{3}{|c|}{ NUMBER OF STUDIES } \\
\hline & & $\begin{array}{l}\text { Total } \\
\text { STUDIES }\end{array}$ & $\begin{array}{l}\text { LIVE } \\
\text { BIRTHS } \\
\text { ONIY } \\
\end{array}$ & $\begin{array}{l}\text { LIVE BIRTHS, } \\
\text { STILLBIRTHS \& } \\
\text { TERMINATIONS }\end{array}$ \\
\hline \multirow{2}{*}{ Western Pacific } & China & 6 & 1 & 5 \\
\hline & Malaysia & 1 & 0 & 1 \\
\hline \multirow{3}{*}{ South East Asia } & India & 3 & 2 & 1 \\
\hline & Pakistan & 1 & 1 & 0 \\
\hline & Thailand & 1 & 1 & 0 \\
\hline \multirow{3}{*}{ Eastern Mediterranean } & Jordan & 2 & 2 & 0 \\
\hline & Saudi Arabia & 2 & 2 & 0 \\
\hline & Iran & 4 & 1 & 3 \\
\hline \multirow{4}{*}{ Europe } & Azerbaijan & 1 & 0 & 1 \\
\hline & Russia & 1 & 1 & 0 \\
\hline & Ukraine & 1 & 0 & 1 \\
\hline & Turkey & 3 & 2 & 1 \\
\hline \multirow{2}{*}{ Africa } & Cameroon & 1 & 1 & 0 \\
\hline & South Africa & 1 & 1 & 0 \\
\hline \multirow{4}{*}{ Americas } & Brazil & 3 & 2 & 1 \\
\hline & Colombia & 1 & 1 & 0 \\
\hline & Peru & 1 & 1 & 0 \\
\hline & Chile & 4 & 1 & 3 \\
\hline
\end{tabular}

As expected, when comparing IQRs as the robust predictions, overall NTD burden estimates were found to be higher in the live births, stillbirths and terminations group in comparison to studies that included only live births, while spina bifida was the most commonly reported NTD type. Moreover, there is internal consistency in the presented estimates, because the sum of the specific NTD types always fits into the "envelope" of all NTDs.

\section{DISCUSSION}

This systematic literature review aimed to examine the burden of NTD in LMIC. It is, to our knowledge, the first study to quantitatively estimate the total NTD burden in LMIC. As such, the burden estimates can be successfully used in the much-needed preventive policy development in LMIC with high risk of NTD.

The results from the 37 selected studies [10-13,23-55] suggest that NTD burden is approximately twice as high, if not higher, in LMIC than in high-income countries [56-58]. The findings from live birth-only studies showed that the median total NTD burden is 1.67 per 1000 live births, although there were reports of significantly higher values, with a maximum burden as high as $12.41 / 1000$. The overall median is greater in studies where live births, stillbirths and terminations were taken into account, where the bur-
Table 4. Studies that reported rates for total NTD burden based on live births only

\begin{tabular}{|c|c|c|c|}
\hline AUtHor AND REFERENCE & SAMPLE SIZE & Cases & RAIE (PER 1000 UVE BIRTHS) \\
\hline Amarin et al. [26] & 61447 & 16 & 0.95 \\
\hline Aqrabawi [11] & 5088 & 33 & 6.50 \\
\hline Asindi et al. [27] & 82176 & 64 & 0.78 \\
\hline Bademci et al. [28] & 5499 & 17 & 3.09 \\
\hline Behrooz et al. [29] & 13262 & 56 & 4.22 \\
\hline Chen et al. [30] & 26599 & 48 & 1.80 \\
\hline Cherian et al. [31] & 1218 & 10 & 8.21 \\
\hline Cortes et al. [32] & 59627 & 67 & 1.12 \\
\hline Costa et al. [33] & 9386 & 11 & 1.17 \\
\hline Gu et al. [13] & 6420 & 25 & 3.89 \\
\hline Hertrampf et al. [34] & 117740 & 114 & 0.97 \\
\hline Kaur et al. [35] & 7400 & 5 & 0.68 \\
\hline Khattak et al. [36] & 5560 & 69 & 12.41 \\
\hline Mandiracioglu et al. [37] & 36331 & 56 & 1.54 \\
\hline Njamnshi et al. [38] & 52710 & 98 & 1.86 \\
\hline Pachajoa et al. [39] & 32995 & 55 & 1.67 \\
\hline Petrova et al. [40] & 141159 & 298 & 2.11 \\
\hline Pacheco et al. [41] & 24964 & 124 & 4.97 \\
\hline Ricks et al. [42] & 35974 & 72 & 2.00 \\
\hline Safdar et al. [24] & 33489 & 42 & 1.25 \\
\hline Sayed et al. [25] & 46021 & 45 & 0.98 \\
\hline Wasant et al. [43] & 180000 & 114 & 0.63 \\
\hline Yuskiv et al. [33] & 75609 & 38 & 0.50 \\
\hline
\end{tabular}

den is 2.55 per 1000 and maximum reported burden of 19.94/1000. This is expected, as a considerable proportion of NTD result in stillbirths and terminations $[59,60]$.

Significant discrepancies between reported burdens from the same country were sometimes observed. These differences were attributed to different study settings, for example in rural and urban India $[31,35,45]$, or different time periods as seen in two studies from Jordan $[11,26]$. Extremely high burden of NTD of 13.79 and 19.94 was observed in two studies from China, although the samples were rather small, indicating a possible selection bias $[10,13]$.

Regardless of the progress in control of NTDs observed in high-income countries, NTD continue to be a problem of significant public health impact in LMIC. NTD have detrimental physical and emotional effects on the affected children and their caregivers, and may present a life-long important and often insurmountable economic problem, especially to poor families [52]. The cost of raising a child with spina bifida from birth to 18 years of age in Chile was estimated to be around US\$120000 [34]. These expenses, apart from causing individual deprivation, are a significant economic burden on the level of the whole society, causing a vicious circle of poverty in the LMIC.

Table 3. A summary of estimates of the burden of neural tube defects and its sub-types from 37 retained studies from low and middle-income countries

\begin{tabular}{|c|c|c|c|c|c|c|}
\hline Studied OUtCoME & Denominator & Number OF Studies & MEDIAN (PER 1000) & INTER-QUARTILE RANGE (PER 1000) & Minimum(Per 1000) & MaXIMUM (PER 1000) \\
\hline \multirow{2}{*}{ All neural tube defects } & LB & 23 & 1.67 & $0.98-3.49$ & 0.50 & 12.41 \\
\hline & $\mathrm{LB}+\mathrm{SB}+\mathrm{TP}$ & 17 & 2.55 & $1.56-3.91$ & 0.86 & 19.94 \\
\hline \multirow{2}{*}{ Spina bifida } & LB & 14 & 1.13 & $0.75-1.73$ & 0.38 & 5.90 \\
\hline & $\mathrm{LB}+\mathrm{SB}+\mathrm{TP}$ & 15 & 1.04 & $0.67-2.48$ & 0.35 & 5.81 \\
\hline \multirow{2}{*}{ Anencephaly } & LB & 13 & 0.25 & $0.08-1.07$ & 0.01 & 11.33 \\
\hline & $\mathrm{LB}+\mathrm{SB}+\mathrm{TP}$ & 16 & 1.03 & $0.67-1.60$ & 0.30 & 8.26 \\
\hline \multirow{2}{*}{ Encephalocele } & LB & 9 & 0.15 & $0.08-0.23$ & 0.03 & 0.39 \\
\hline & $\mathrm{LB}+\mathrm{SB}+\mathrm{TP}$ & 13 & 0.21 & $0.16-0.28$ & 0.07 & 2.65 \\
\hline
\end{tabular}

$\mathrm{LB}$ - live births; $\mathrm{LB}+\mathrm{SB}+\mathrm{TP}$ - live births, stillbirths and terminated pregnancies 
Table 5. Studies that reported rates for the burden of spina bifida based on live births only

\begin{tabular}{|c|c|c|c|}
\hline AUtHOR AND REFERENCE & SAMPLE SIZE & Cases & RATE(PER 1000 IVE BIRTHS) \\
\hline Aqrabawi [11] & 5088 & 30 & 5.90 \\
\hline Asindi et al. [27] & 82176 & 46 & 0.56 \\
\hline Bademci et al. [28] & 5499 & 11 & 2.00 \\
\hline Behrooz et al. [29] & 13262 & 23 & 1.73 \\
\hline Cherian et al. [31] & 1218 & 6 & 4.93 \\
\hline Costa et al. [44] & 9386 & 7 & 0.75 \\
\hline Khattak et al. [36] & 5560 & 5 & 0.90 \\
\hline Mandiracioglu et al. [37] & 36331 & 43 & 1.18 \\
\hline Njamnshi et al. [38] & 52710 & 65 & 1.23 \\
\hline Petrova et al. [40] & 141159 & 147 & 1.04 \\
\hline Ricks et al. [42] & 35974 & 62 & 1.72 \\
\hline Safdar et al. [24] & 33489 & 36 & 1.07 \\
\hline Sayed et al. [25] & 46021 & 25 & 0.54 \\
\hline Yuskiv et al. [33] & 75609 & 29 & 0.38 \\
\hline
\end{tabular}

Table 6. Studies that reported rates for the burden of anencephaly based on live births only

\begin{tabular}{lrrr} 
Author and REFERENCE & SAMPLE SIZE & CASES & RATE (PER 1000 LIVE BIRTHS) \\
\hline Asindi et al. [27] & 82176 & 3 & 0.04 \\
\hline Behrooz et al. [29] & 13262 & 30 & 2.26 \\
\hline Cherian et al. [3]] & 1218 & 3 & 2.46 \\
\hline Costa et al. [44] & 9386 & 1 & 0.11 \\
\hline Khattak et al. [36] & 5560 & 63 & 11.33 \\
\hline Mandiracioglu et al. [45] & 36331 & 4 & 0.11 \\
\hline Njamnshi et al. [38] & 52710 & 4 & 0.08 \\
\hline Petrova et al. [40] & 141159 & 151 & 1.07 \\
\hline Ricks et al. [42] & 35974 & 10 & 0.28 \\
\hline Safdar et al. [24] & 33489 & 1 & 0.03 \\
\hline Sayed et al. [25] & 46021 & 17 & 0.37 \\
\hline Wasant et al. [43] & 180000 & 45 & 0.25 \\
\hline Yuskiv et al. [33] & 75609 & 1 & 0.01
\end{tabular}

Hundreds of thousands of live born babies are affected by NTD in LMIC, which remain an important and preventable cause of morbidity and mortality. Thus, effective policies for prevention are vital to reduce the burden of NTD on individuals and on society. Up to now, more than 59 countries have committed to mandatory fortification programmes $[59,61,62]$. However, many LMIC still have ineffective recommendations and policies towards folic acid uptake. Some countries have recommended the improvement of daily diet and folic acid supplement use, but do not have a mandatory policy $[59,61,62]$. Recommendation provides a good starting point for reducing NTD burden in LMIC. However, many households in LMIC may not be able to afford folic acid supplementation throughout pregnancy [63]. As shown by the example from the US where NTD burden had fallen by $20 \%$ after mandatory fortification, recommendation alone, even without the economic constraint, is not likely to provide a feasible and effective solution [22]. Interestingly, survey conducted in the UK found that there was only a marginal increase in folic acid intake in women who were planning pregnancy [64]. Additionally, around half of all pregnancies in the US are unexpected [58,62], and this figure may be even higher in LMIC where there may be limited availability of contraception.

Despite obvious benefits, before promoting folic acid fortification, many factors must be considered. Currently no country in the European Union has compulsory fortification schemes due to risk consideration and campaigns
Table 7. Studies that reported rates for the burden of encepalocele based on live births only

\begin{tabular}{|c|c|c|c|}
\hline AUTHOR AND REFERENCE & SAMPLE SIZE & Cases & RATE (PER 1000 LIVE BIRTHS) \\
\hline Aqrabawi [11] & 5088 & 2 & 0.39 \\
\hline Asindi et al. [27] & 82176 & 15 & 0.18 \\
\hline Behrooz et al. [29] & 13262 & 3 & 0.23 \\
\hline Costa et al. [44] & 9386 & 3 & 0.32 \\
\hline Mandiracioglu et al. [45] & 36331 & 1 & 0.03 \\
\hline Njamnshi et al. [38] & 52710 & 5 & 0.09 \\
\hline Safdar et al. [24] & 33489 & 5 & 0.15 \\
\hline Wasant et al. [43] & 180000 & 14 & 0.08 \\
\hline Yuskiv et al. [33] & 75609 & 3 & 0.03 \\
\hline
\end{tabular}

Table 8. Studies that reported rates for total NTD burden based on live births, stillbirths and terminations of pregnancy

\begin{tabular}{lrrc} 
Author AND REFERENGE & SAMPLE SIzE & CASES & $\begin{array}{c}\text { RATE (PER 1000 LIVE } \\
\text { BIRTHS STILLBRTHS } \\
\text { AND TERMINATIONS) }\end{array}$ \\
Aguiar et al. [46] & 18807 & 89 & 4.73 \\
\hline Cortes et al. [32] & 60072 & 94 & 1.56 \\
\hline Cortes et al. [12] & 486779 & 419 & 0.86 \\
\hline Dai et al. [46] & 2281616 & 2873 & 1.30 \\
\hline Golalipour et al. [47] & 37951 & 109 & 2.87 \\
\hline Golalipour et al. [12] & 30639 & 78 & 2.55 \\
\hline Golalipour et al. [48] & 49534 & 194 & 3.91 \\
\hline Gu et al. [13] & 6420 & 128 & 19.94 \\
\hline Li et al. [10] & 11534 & 159 & 13.79 \\
\hline Liu et al. [49] & 99888 & 122 & 1.22 \\
\hline Mahadevan et al. [45] & 54738 & 310 & 5.66 \\
\hline Nazer et al. [50] & 434624 & 740 & 1.70 \\
\hline Noraihan et al. [51] & 34109 & 37 & 1.08 \\
\hline Onrat et al. [52] & 8631 & 31 & 3.59 \\
\hline Rad et al. [53] & 14121 & 117 & 2.57 \\
\hline Yuskiv et al. [33] & 75928 & 159 & 2.09 \\
\hline Zhang et al. [54] & 62373 & 126 & 2.02 \\
\hline
\end{tabular}

Table 9. Studies that reported rates for the burden of spina bifida based on live births, stillbirths and terminations of pregnancy

\begin{tabular}{|c|c|c|c|}
\hline AUtHor AND refERENCE & SAMPLE SIZE & Cases & $\begin{array}{l}\text { RATE (PER } 1000 \text { LIVE BIRTHS, } \\
\text { STILLBIRTHS AND TERMINATIONS) }\end{array}$ \\
\hline Cortes et al. [32] & 60072 & 46 & 0.77 \\
\hline Cortes et al. [12] & 486779 & 204 & 0.42 \\
\hline Golalipour et al. [47] & 37951 & 62 & 1.63 \\
\hline Golalipour et al. [12] & 30639 & 39 & 1.27 \\
\hline Gu et al. [13] & 6420 & 25 & 3.89 \\
\hline Li et al. [10] & 11534 & 67 & 5.81 \\
\hline Liu et al. [49] & 99888 & 59 & 0.59 \\
\hline Mahadevan et al. [45] & 54738 & 170 & 3.11 \\
\hline Noraihan et al. [51] & 34109 & 12 & 0.35 \\
\hline Onrat et al. [52] & 8631 & 9 & 1.04 \\
\hline Yuskiv et al. [33] & 75928 & 64 & 0.84 \\
\hline Aguiar et al. [55] & 18807 & 47 & 2.49 \\
\hline Dai et al. [46] & 2281616 & 1369 & 0.60 \\
\hline Nazer et al. [50] & 434624 & 374 & 0.86 \\
\hline Rad et al. [53] & 14121 & 35 & 2.48 \\
\hline
\end{tabular}

Table 10. Studies that reported rates for the burden of anencephaly based on live births, stillbirths and terminations of pregnancy

\begin{tabular}{|c|c|c|c|}
\hline AUtHor AND refERENCE & SAMPLE SIZE & Cases & $\begin{array}{l}\text { RATE (PER } 1000 \text { LIVE BIRTHS, } \\
\text { STILLBIRTHS AND TERMINATIONS) }\end{array}$ \\
\hline Aguiar et al. [55] & 18807 & 24 & 1.28 \\
\hline Cortes et al. [32] & 60072 & 37 & 0.62 \\
\hline Cortes et al. [12] & 486779 & 147 & 0.30 \\
\hline Dai et al. [46] & 2281616 & 1140 & 0.50 \\
\hline Golalipour et al. [47] & 37951 & 43 & 1.40 \\
\hline Golalipour et al. [12] & 30639 & 35 & 0.92 \\
\hline Golalipour et al. [48] & 49534 & 56 & 1.13 \\
\hline Gu et al. [13] & 6420 & 53 & 8.26 \\
\hline Li et al. [10] & 11534 & 75 & 6.50 \\
\hline Liu et al. [49] & 99888 & 42 & 0.42 \\
\hline Mahadevan et al. [45] & 54738 & 98 & 1.80 \\
\hline Nazer et al. [50] & 434624 & 311 & 0.72 \\
\hline Noraihan et al. [51] & 34109 & 25 & 0.73 \\
\hline Onrat et al. [52] & 8631 & 12 & 1.39 \\
\hline Rad et al. [53] & 14121 & 78 & 5.52 \\
\hline Yuskiv et al. [33] & 75928 & 62 & 0.82 \\
\hline
\end{tabular}


Table 11. Studies that reported rates for the burden of encephalocele based on live births, stillbirths and terminations of pregnancy

\begin{tabular}{|c|c|c|c|}
\hline Author and reference & SaMPLE SIZE & Cases & $\begin{array}{l}\text { RATE (PER } 1000 \text { LIVE } \\
\text { BIRTHS STILBBRTHS } \\
\text { AND TERMINATIONS) }\end{array}$ \\
\hline Aguiar et al. [55] & 18807 & 5 & 0.27 \\
\hline Cortes et al. [32] & 60072 & 11 & 0.18 \\
\hline Dai et al. [46] & 2281616 & 365 & 0.16 \\
\hline Golalipour et al. [47] & 37951 & 4 & 0.11 \\
\hline Golalipour et al. [12] & 30639 & 4 & 0.13 \\
\hline Gu et al. [13] & 6420 & 17 & 2.65 \\
\hline Li et al. [10] & 11534 & 17 & 1.47 \\
\hline Liu et al. [49] & 99888 & 7 & 0.07 \\
\hline Mahadevan et al. [45] & 54738 & 36 & 0.66 \\
\hline Nazer et al. [50] & 434624 & 91 & 0.21 \\
\hline Onrat et al. [52] & 8631 & 2 & 0.23 \\
\hline Rad et al. [53] & 14121 & 4 & 0.28 \\
\hline Yuskiv et al. [3 & 75928 & 12 & 0.16 \\
\hline
\end{tabular}

against 'mass medication' [65,66]. Safety, ethics and economic feasibility of a FAF programme must be taken into account before implementing such a policy, especially on a whole-country level. Nevertheless, current high burden of NTD in LMIC stresses the need for a comprehensive prevention program.

For consistent and reliable estimates on burden of NTD, it is important to set up vital and birth registration documentation programs in countries that lack coherent information on NTD burden. Not only will this aid in the prevention and treatment of NTD, but it will also enable policy makers to monitor the benefits of implemented prevention programs. This may be particularly important for countries in the African WHO region, where a high NTD burden is expected, but from which only a few studies have been published $[67,68]$.
The reported NTD burden was estimated based on a limited number of available studies, some with very variable sample sizes that differed in inclusion of stillbirths and terminated births in the study design. We could not use metaanalysis, because studies came from such heterogeneous contexts that we didn't feel it was justified to present anything beyond simple median and IQR in this initial estimate. This is partly because not all studies adhered to ICD-10 classification of NTD and were not uniformly conducted regarding method of diagnosis and reporting of NTD type, enabling potential over- or under-estimation of NTD burden through misdiagnosis. Also, the technical restrictions of accounting for all stillbirths and terminations in the examined studies limited the precision of our estimated burden in that population [68].

Finally, the data was available from studies conducted in only 18 countries, implying that the studied sample is unlikely to be representative of all the LMIC globally. Regardless of these significant limitations, it is our opinion that the estimated burdens reported in the results provide useful data for initial assessment of NTD burden in LMIC. An increase in high quality research on NTD, especially with regards to gender and geographical regions, should be prioritised to allow more accurate NTD estimates. This would make the burden of the problem easier to estimate in a more credible way, and allow effective planning of prevention and intervention to minimise the risks for NTD.
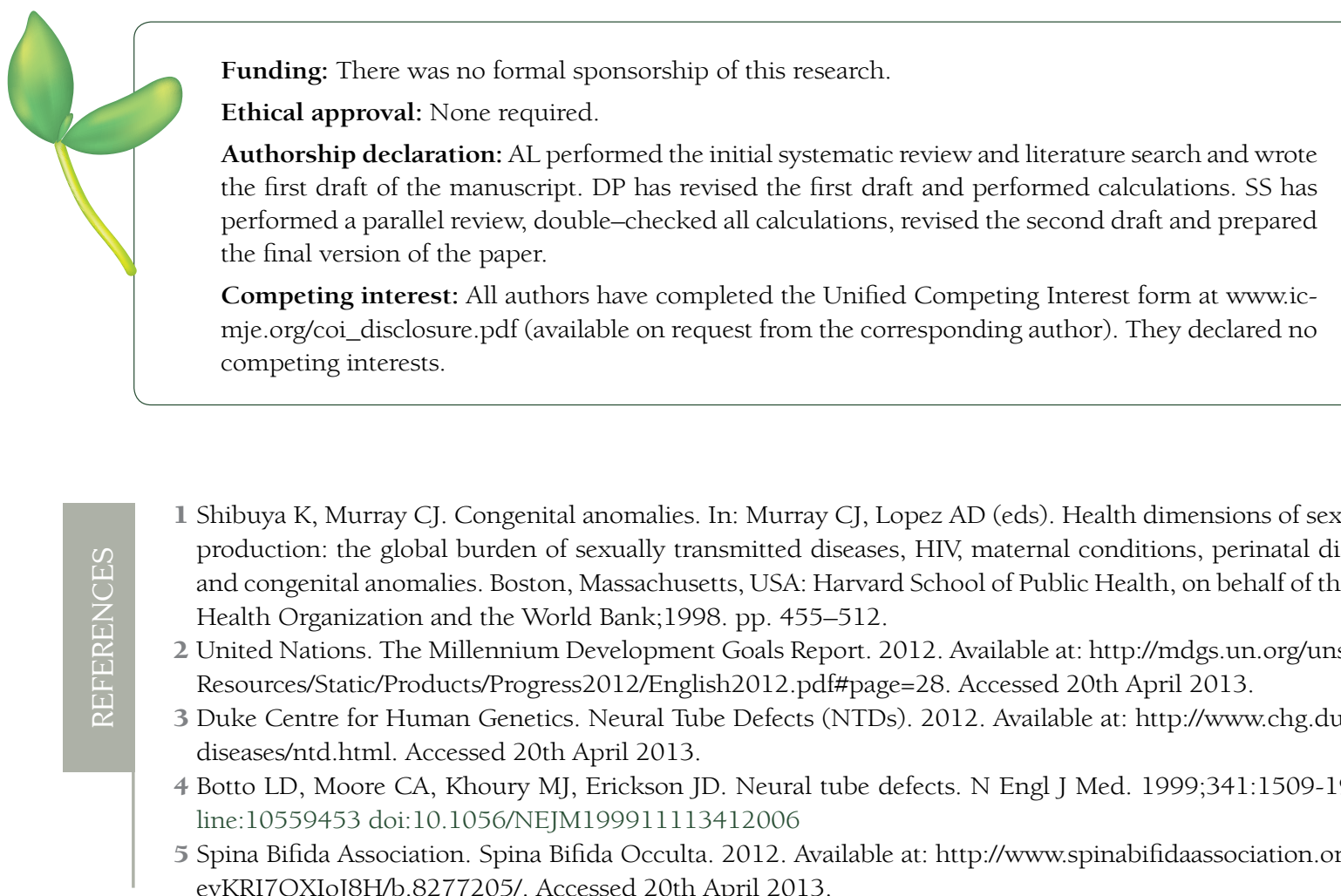

1 Shibuya K, Murray CJ. Congenital anomalies. In: Murray CJ, Lopez AD (eds). Health dimensions of sex and reproduction: the global burden of sexually transmitted diseases, HIV, maternal conditions, perinatal disorders, and congenital anomalies. Boston, Massachusetts, USA: Harvard School of Public Health, on behalf of the World Health Organization and the World Bank;1998. pp. 455-512.

2 United Nations. The Millennium Development Goals Report. 2012. Available at: http://mdgs.un.org/unsd/mdg/ Resources/Static/Products/Progress2012/English2012.pdf\#page=28. Accessed 20th April 2013.

3 Duke Centre for Human Genetics. Neural Tube Defects (NTDs). 2012. Available at: http://www.chg.duke.edu/ diseases/ntd.html. Accessed 20th April 2013.

4 Botto LD, Moore CA, Khoury MJ, Erickson JD. Neural tube defects. N Engl J Med. 1999;341:1509-19. Medline:10559453 doi:10.1056/NEJM199911113412006

5 Spina Bifida Association. Spina Bifida Occulta. 2012. Available at: http://www.spinabifidaassociation.org/site/c. evKRI7OXIoJ8H/b.8277205/. Accessed 20th April 2013. 
6 Christianson A, Howson CP, Modell B. Global Report on Birth Defects: The Hidden Toll of Dying and Disabled children. March of Dimes. 2006. Available at: http://www.marchofdimes.com/mission/globalprograms_birthdefectsreport.html. Accessed 20th April 2013.

7 Kirke PN, Molloy AM, Daly LE, Burke H, Weir DG, Scott JM. Maternal plasma folate and vitamin B12 are independent risk factors for neural tube defects. Q J Med. 1993;86:703-8. Medline:8265769

8 Bjorklund NK, Gordan R. A hypothesis linking low folate intake to neural tube defects due to failure of posttranslation methylations of the cytoskeletion. Int J Dev Biol. 2006;50:135-41. Medline:16479482 doi:10.1387/ ijdb.052102nb

9 Wang ZP, Shang XX, Zhao ZT. Low maternal vitamin B12 is a risk factor for neural tube defects: a meta-analysis. J Matern Fetal Neonatal Med. 2012;25:389-94. Medline:21627554 doi:10.3109/14767058.2011.580800

10 Li Z, Ren A, Zhang L, Ye R, Li S, Zheng J, et al. Extremely high prevalence of NTD in a 4-county area of Shanxi Province, China. Birth Defects Res A Clin Mol Teratol. 2006;76:237-40. Medline:16575897 doi:10.1002/ bdra. 20248

11 Aqrabawi HE. Incidence of neural tube defects among neonates at King Hussein Medical Centre, Jordan. East Mediterr Health J. 2005;11:819-23. Medline:16700398

12 Golalipour M, Najafi L, Keshtkar A. Neural tube defects in native Fars ethnicity in Northern Iran. Iran J Public Health. 2010;39:116-23. Medline:23113030

13 Gu X, Lin L, Zheng X, Zhang T, Song X, Wang J, et al. High prevalence of NTDs in Shanxi Province: a combined epidemiological approach. Birth Defects Res A Clin Mol Teratol. 2007;79:702-7. Medline:17729293 doi:10.1002/ bdra. 20397

14 Suarez L, Felkner M, Brender JD, Canfield M, Hendricks K. Maternal exposures to cigarette smoke, alcohol and street drugs and neural tube defect occurrence in offspring. Matern Child Health J. 2008;12:394-401. Medline:17641961 doi:10.1007/s10995-007-0251-y

15 Li Z, Zhang L, Ye R, Pei L, Liu J, Zheng X, et al. Indoor air pollution from coal combustion and the risk of neural tube defects in a rural population in Shanxi Province, China. Am J Epidemiol. 2011;174:451-8. Medline:21659350 doi:10.1093/aje/kwr108

16 Tunçbilek E, Boduroglu K, Alikasifoglu M. Neural tube defects in Turkey: prevalence, distribution and risk factor. Turk J Pediatr. 1999;41:299-305. Medline:10770089

17 Watkins ML, Rasmussen SA, Honein MA, Botto LD, Moore CA. Maternal obesity and risk for birth defects. Pediatrics. 2003;111:1152-8. Medline:12728129

18 Mayo Medical Laboratories. Test ID: MAFP. 2013. Available at: http://www.mayomedicallaboratories.com/testcatalog/Clinical+and+Interpretive/81169. Accessed 21 April 2013.

19 Mayo Medical Laboratories. Test ID: ACHE. 2013. Available at: http://www.mayomedicallaboratories.com/testcatalog/Clinical+and+Interpretive/9287. Accessed 21 April 2013.

20 National Cancer Institute. Computed Tomography (CT): A guide for Health Care. 2012. Available at: http:// www.cancer.gov/cancertopics/causes/radiation/radiation-risks-pediatric-CT. Accessed 21st April 2013.

21 Prevention of neural tube defects: results of the Medical Research Council Vitamin Study. Lancet. 1991;338:1317. Medline:1677062 doi:10.1016/0140-6736(91)90133-A

22 Honein MA, Paulozzi LJ, Mathews TJ, Erickson JD, Wong LY. Impact of folic acid fortification of the US food supply on the occurrence of neural tube defect. JAMA. 2001;285:2981-6. Medline:11410096 doi:10.1001/ jama.285.23.2981

23 Cortés F, Mellado C, Pardo RA, Villarroel LA, Hertrampf E. Wheat flour fortification with folic acid: changes in neural tube defect rates in Chile. Am J Med Genet A. 2012;158A:1885-90. Medline:22711368 doi:10.1002/ ajmg.a.35430

24 Safdar OY, Al-Dabbagh AA, Abuelieneen WA, Kari JA. Decline in the incidence of neural tube defects after the national fortification of flour (1997-2005). Saudi Med J. 2007;28:1227-9. Medline:17676207

25 Sayed AR, Bourne D, Pattinson R, Nixon J, Henderson B. Decline in the prevalence of neural tube defects following folic acid fortification and its cost-benefit in South Africa. Birth Defects Res A Clin Mol Teratol. 2008;82:211-6. Medline:18338391 doi:10.1002/bdra.20442

26 Amarin ZO, Obeidat AZ. Effect of folic acid fortification on the incidence of neural tube defects. Paediatr Perinat Epidemiol. 2010;24:349-51. Medline:20618724 doi:10.1111/j.1365-3016.2010.01123.x

27 Asindi A, Al-Shehri A. Neural tube defects in the Asir Region of Saudi Arabia. Ann Saudi Med. 2001;21:26-9. Medline: 17264584

28 Bademci G, Saygun M, Batay F, Cakmak A, Basar H, Anbarci H, et al. Prevalence of primary tethered cord syndrome associated with occult spinal dysraphism in primary school children in Turkey. Pediatr Neurosurg. 2006;42:4-13. Medline:16357495 doi:10.1159/000089503

29 Behrooz A, Gorjizadeh MH. Prevalence and correlates of neural tube defects in South West Iran: Retrospective analysis. Sultan Qaboos Univ Med J. 2007;7:31-4. Medline:21654942

30. Chen G, Song Z, Ji Y, Zhang L, Pei L, Chen J, et al. Prevention of NTDs with periconeptional multivitamin supplementation containing folic acid in China. Birth Defect Res A Clin Mol Teratol. 2008;82:592-6.

31 Cherian A, Seena S, Bullock RK, Antony AC. Incidence of neural tube defects in the least-developed area of India: a population-based study. Lancet. 2005;366:930-1. Medline:16154020 doi:10.1016/S0140-6736(05)67319-9 
32 Cortés F, Mellado C, Hertrampf E, Alliende A, Castillo S. Frequency of neural tube defects in public maternity during 1999 in Santiago, Chile. Rev Med Chil. 2001;129:277-84. Medline:11372295

33 Yuskiv N, Andelin CO, Polischuk S, Shevchuk O, Sosynyuk Z, Vihovska T, et al. High rates of neural tube defects in Ukraine. Birth Defects Res A Clin Mol Teratol. 2004;70:400-2. Medline:15211709 doi:10.1002/ bdra.20020

34 Hertrampf E, Cortés F. National food fortification program with folic acid in Chile. Food Nutr Bull. 2008;29(2 Suppl):S231-7. Medline:18709898

35 Kaur G, Srivastav J, Kaur A, Huria A, Goel P, Kaur R, et al. Maternal serum second trimester screening for the chromosomal disorders and neural tube defects in a government hospital of North India. Prenat Diagn. 2012;32:1192-6. Medline:23055346 doi:10.1002/pd.3984

36 Khattak ST, Khan M, Naheed T, Khattak IU, Ismali M. Prevalence and management of anencephaly at Saidu Teaching Hospital. J Ayub Med Coll Abbottabad. 2010;22:61-3. Medline:22455263

37 Mandiracioğlu A, Ulman I, Lüleci E, Ulman C. The incidence and risk factors of neural tube defects in Izmir, Turkey: a nested case-control study. Turk J Pediatr. 2004;46:214-20. Medline:15503473

38 Njamnshi AK, Djientcheu Vde P, Lekoubou A, Guemse M, Obama MT, Mbu R, et al. Neural tube defects are rare among black Americans but not in sub-Saharan black Africans: the case of Yaounde - Cameroon. J Neurol Sci. 2008;270:13-7. Medline:18295800 doi:10.1016/j.jns.2008.01.010

39 Pachajoa H, Ariza Y, Isaza C, Méndez F. Major birth defects in a third-level hospital in Cali, Colombia 20042008. Rev Salud Publica (Bogota). 2011;13:152-62. Medline:22030798

40 Petrova JG, Vatskjold A. The incidence of neural tube defects in Norway and the Arkhangelskaja Oblast in Russia and the association with maternal age. Acta Obstet Gynecol Scand. 2009;88:667-72. Medline:19353336 doi:10.1080/00016340902898008

41 Pacheco SS, Braga C, Souza AI, Figueiroa JN. Neural tube defects prevalence in newborn infants in the Women Care Center of the Instituto Materno Infantil Prof. Fernando Figueira. Rev Bras Saude Mater Infant. 2006;6 Suppl 1:S35-42.

42 Ricks DJ, Rees CA, Osborn KA, Crookston BT, Leaver K, Merrill SB, et al. Peru's national folic acid fortification program and its effect on neural tube defects in Lima. Rev Panam Salud Publica. 2012;32:391-8. Medline:23370181 doi:10.1590/S1020-49892012001400001

43 Wasant P, Sathienkijkanchai A. Neural tube defects at Sirirajhospital, Bangkok, Thailand - 10 years review (1990-1999). J Med Assoc Thai. 2005;88 Suppl 8:S92-9. Medline:16858850

44 Costa CM, da Gama SG, Leal Mdo C. Congenital malformations in Rio de Janeiro, Brazil: prevalence and associated factors. Cad Saude Publica. 2006;22:2423-31. Medline:17091179 doi:10.1590/S0102-311X2006001100016

45 Mahadevan B, Bhat BV. Neural tube defects in Pondicherry. Indian J Pediatr. 2005;72:557-9. Medline:16077237 doi:10.1007/BF02724177

46 Dai L, Zhu J, Zhou G, Wang Y, Wu Y, Miao L, et al. Dynamic monitoring of neural tube defects in China during 1996 to 2000. Zhonghua Yu Fang Yi Xue Za Zhi. 2002;36:402-5. Medline:12641978

47 Golalipour MJ, Mobasheri E, Vakilil MA, Keshtkar AA. Epidemiology of neural tube defects in north Iran, 1998 - 2003. East Mediterr Health J. 2007;13:560-6. Medline:17687828

48 Golalipour MJ, Najafi L, Keshtkar AA. Prevalence of anencephaly in Gorgan, Northern Iran. Arch Iran Med. 2010;13:34-7. Medline:20039767

49 Liu J, Yang GZ, Zhou JL, Cao SP, Chau DH, Kung HF, et al. Prevalence of neural tube defects in economically and socially deprived area of China. Childs Nerv Syst. 2007;23:1119-24. Medline:17450368 doi:10.1007/ s00381-007-0344-3

50 Nazer H J. Congenital malformations in Latin America in the period 1995-2008. Rev Med Chil. 2011;139:728. Medline:21526320

51 Noraihan MN, See MH, Raja R, Baskaran TP, Symonds EM. Audit of birth defects in 34,109 deliveries in a tertiary referral center. Med J Malaysia. 2005;60:460-8. Medline:16570708

52 Onrat ST, Seyman H, Honuk M. Incidence of neural tube defects in Afyonkarahisar, Western Turkey. Genet Mol Res. 2009;8:154-61. Medline:19283682 doi:10.4238/vol8-1gmr552

53 Rad IA, Farrokh-Islamlou HR, Khoshkalam M. Neural tube defects prevalence in a hospital-based study in Urmia. Iran J Child Neurol. 2008;2:19-23.

54 Xiao KZ, Zhang ZY, Su YM, Liu FQ, Yan ZZ, Jiang ZQ, et al. Central nervous system congenital malformations, especially neural tube defects in 29 provinces, metropolitan cities and autonomous regions of China: Chinese Birth Defects Monitoring Program. Int J Epidemiol. 1990;19:978-82. Medline:2084031 doi:10.1093/ije/19.4.978

55 Aguiar MJ, Campos AS, Aguiar RA, Lana AM, Magalhăes RL, Babeto LT. Neural tube defects and associated factors in liveborn and stillborn infants. J Pediatr (Rio J). 2003;79:129-34. Medline:14502333 doi:10.2223/ JPED.964

56 Tinker SC, Cogswell ME, Devine O, Berry RJ. Folic acid intake among U.S. women aged 15-44 years, National Health and Nutrition Examination Survey, 2003-2006. Am J Prev Med. 2010;38:534-42. Medline:20347553 doi:10.1016/j.amepre.2010.01.025 
57 Grosse SD, Waitzman NJ, Romano PS, Mulinare J. Re-evaluation the benefits of folic acid fortification in the United States: economic analysis, regulation and public health. Am J Public Health. 2005;95:1917-22. Medline:16195513 doi:10.2105/AJPH.2004.058859

58 Yen IH, Khoury MJ, Erickson JD, James LM, Waters GD, Berry RJ. The changing epidemiology of neural tube defects. United States, 1968-1989. Am J Dis Child. 1992;146:857-61. Medline:1496959 doi:10.1001/archpedi.1992.02160190089028

59 World Health Organization. Weekly iron-folic acid supplementation (WIFS) in Women of Reproductive age: Its role in promoting optimal maternal and child health. 2009. Available at: http://www.who.int/nutrition/publications/micronutrients/weekly_iron_folicacid.pdf. Accessed 21st April 2013.

60 National Library of Medicine. Spina Bifida. 2013. Available at: http://www.nlm.nih.gov/medlineplus/spinabifida. html. Accessed 20th April 2013.

61 Berry RJ, Bailey L, Mulinare J, Bower C; Folic Acid Working Group. Fortification of flour with folic acid. Food Nutr Bull. 2010;31 Suppl:S22-35. Medline:20629350

62 Crider KS, Bailey LB, Berry RJ. Folic acid fortification - its history, effect, concerns, and future directions. Nutrients. 2011;3:370-84. Medline:22254102 doi:10.3390/nu3030370

63 Chopra M, Campbell H, Rudan I. Understanding the determinants of the complex interplay between cost-effectiveness and equitable impact in maternal and child mortality reduction. J Glob Health. 2012;2:010406. Medline:23198135 doi:10.7189/jogh.01.010406

64 Crozier SR, Robinson SM, Borland SE, Godfrey KM, Cooper C, Inskip H; SWS study group. Do women change their health behaviours in pregnancy? Findings from the Southampton Women's Survey. Paediatr Perinat Epidemiol. 2009;23:446-53. Medline:19689495 doi:10.1111/j.1365-3016.2009.01036.x

65 Russell A. The UK campaign on folic acid and flour fortification. Cerebrospinal Fluid Res. 2006;3 Suppl 1:S33. doi:10.1186/1743-8454-3-S1-S33

66 FAO and WHO. Folate and folic acid. 2002. Available at: http://www.fao.org/docrep/004/Y2809E/y2809e0a. htm. Accessed 25th April 2013.

67 Campbell A, Rudan I. Systematic review of birth cohort studies in Africa. J Glob Health. 2011;1:46-58. Medline:23198102

68 Frey L, Hauser WA. Epidemiology of neural tube defects. Epilepsia. 2003;44 Suppl 3:4-13. Medline:12790881 doi:10.1046/j.1528-1157.44.s3.2.x 